\title{
Anxiety level on the implementation of the student's essay at Faculty of Medicine, Udayana University
}

Nível de ansiedade na implementação da redação do aluno na Faculdade de Medicina da Universidade de Udayana

Nivel de ansiedad en la implementación del ensayo del estudiante en la Facultad de Medicina de la Universidad de Udayana

I Nyoman Wahyu Erlangga Mahaendrayasa ORCID: https://orcid.org/0000-0002-9840-3304 Medical Faculty Udayana University, Indonesia E-mail: wahyuerlangga081@gmail.com

Cokorda Agung Wahyu Purnamasidhi ORCID: https://orcid.org/0000-0002-1646-3793 Medical Faculty Udayana University, Indonesia E-mail: purnamasidhi@unud.ac.id

I Gde Haryo Ganesha ORCID: https://orcid.org/0000-0002-0173-2057 Medical Faculty Udayana University, Indonesia E-mail: purnamasidhi@unud.ac.id

\begin{abstract}
In Indonesia, thesis is a scientific paper written by prospective undergraduates as a requirement to obtain a bachelor's degree in an undergraduate study program which of course in the process often experiences anxiety which will affect the performance of students on campus, especially students of the Faculty of Medicine. This study aims to determine the level of anxiety in the implementation of student essay at the Faculty of Medicine, Udayana University. This research is a descriptive research with survey method. The number of samples is 170 respondents and sampling method using random sampling technique. The results of the study showed the prevalence of anxiety levels in students of the Faculty of Medicine, Udayana University class 2017 in the mild category as many as 135 people (79.4\%), the moderate category as many as 31 people $(18.2 \%)$ and the high category as many as 4 people $(2.4 \%)$. For each study program, the level of anxiety experienced is relatively the same, the highest category in the mild category, then followed by the moderate category and the last with the smallest number, namely the high category.
\end{abstract}

Keywords: Anxiety level; Medical student; Prevalence; Thesis.

\section{Resumo}

$\mathrm{Na}$ Indonésia, tese é um artigo científico escrito por futuros alunos de graduação como requisito para a obtenção do grau de bacharel em um programa de estudos de graduação que, obviamente, no processo, muitas vezes experimenta ansiedade que afetará o desempenho dos alunos no campus, especialmente alunos da Faculdade de Medicina. Este estudo tem como objetivo determinar o nível de ansiedade na execução de ensaio do aluno na Faculdade de Medicina da Universidade de Udayana. Esta pesquisa é uma pesquisa descritiva com método survey. O número de amostras é de 170 respondentes e método de amostragem usando técnica de amostragem aleatória. Os resultados do estudo mostraram a prevalência de níveis de ansiedade em alunos da Faculdade de Medicina da Udayana University turma 2017 na categoria leve em até 135 pessoas $(79,4 \%)$, na categoria moderada em até 31 pessoas $(18,2 \%)$ e a categoria alta chega a 4 pessoas $(2,4 \%)$. Para cada programa de estudo, o nível de ansiedade experimentado é relativamente o mesmo, a categoria mais alta na categoria leve, seguida pela categoria moderada e a última com o menor número, ou seja, a categoria alta.

Palavras-chave: Nível de ansiedade; Tese; Prevalência; Estudante de medicina.

\section{Resumen}

En Indonesia, una tesis es un artículo científico escrito por futuros estudiantes como requisito para obtener una licenciatura en un programa de estudios de pregrado que, por supuesto, en el proceso a menudo experimenta ansiedad que afectará el desempeño de los estudiantes en el campus, especialmente los estudiantes de la Facultad de Medicina. Este estudio tiene como objetivo determinar el nivel de ansiedad en la implementación de ensayo de un estudiante de la Facultad de Medicina de la Universidad de Udayana. Esta investigación es una investigación descriptiva con método de encuesta. El número de muestras es de 170 encuestados y el método de muestreo utiliza la técnica de 
muestreo aleatorio. Los resultados del estudio mostraron la prevalencia de niveles de ansiedad en estudiantes de la Facultad de Medicina, clase 2017 de la Universidad de Udayana en la categoría leve hasta 135 personas (79,4\%), la categoría moderada hasta 31 personas $(18,2 \%)$ y la categoría alta hasta 4 personas $(2,4 \%)$. Para cada programa de estudio, el nivel de ansiedad experimentado es relativamente el mismo, la categoría más alta en la categoría leve, luego seguida por la categoría moderada y la última con el número más pequeño, es decir, la categoría alta.

Palabras clave: Nivel de ansiedad; Tesis; Predominio; Estudiante de medicina.

\section{Introduction}

Anxiety disorder is a psychological problem which is a physiological response that is usually to avoid several stimulus such as threats that are encountered in various situations in life and even in the educational process (Chandratika et al., 2014). Anxiety is also an excessive worry that can interfere with daily activities which can be followed easily by fatigue or difficulty concentrating (Annisa, 2018). An anxiety if it can be handled properly will be able to be a motivator that can improve a person's quality of life, but on the other hand if the anxiety can't be handled properly then a person's quality of life will not increase or even decrease (Thinagar et al., 2017; Yanti et al., 2013). Thesis is something that is used as one of the educational requirements, especially academic (Mastuti et al., 2010). Thesis is used as evidence of ability a person's academic career in a study that is required for students to obtain a bachelor's degree with the aim that students are more likely to express their ideas more systematically (Hariwijaya et al., 2008). Anxiety in students in the process of the preparation of the final assignment (thesis) can be classified as a symptom of anxiety (anxiety) or more specifically academic anxiety (academic anxiety) which when it reaches a high level will have a negative impact (Ottens, 1991). This study aims to determine the level of anxiety in the implementation of student's essay at the Faculty of Medicine, Udayana University. Essay can be one of the things that causes anxiety or stress, especially among students, one of the causes is the lack of achievement motivation and creativity of the students themselves (Situmorang et al., 2016).

The level of anxiety experienced by medical students tends to be higher than the general population at the same age (Lyndon et al., 2014). In Pakistan, the anxiety rate of medical students in pursuing education reaches 46.07\% (Jaadoon et al., 2010). Through research conducted at the Faculty of Medicine, University of North Sumatra obtained from 100 medical students , 35\% (35 people) experienced low levels of anxiety, 61\% (61 people) experienced moderate levels of anxiety and 4\% (4 people) experienced high levels of anxiety (Adiguna et al., 2015). Based on research conducted at STIKES Muhammadiyah Klaten, $50 \%$ experienced moderate levels of anxiety and the other $50 \%$ experienced low levels of anxiety, none of them did not experience anxiety only experiencing it at different levels (Hastuti et al., 2016).

The level of anxiety experienced by medical faculty students is quite high, this is due to differences in special stressors experienced by medical students such as community stigma, the education system or professional demands that will affect the productivity of the educational process (Marsella et al., 2018).

\section{Method}

This research is a descriptive study with a survey method with a sample of 170 respondents and the sampling method used is random sampling technique to find out the the level of anxiety of medical students on the implementation of the thesis at the Faculty of Medicine, Udayana University. The keywords for this research are anxiety level, thesis, prevalence, medical student.

\section{Results}

Participants in this study were respondents who met the eligibility criteria, namely willing to fill out the questionnaire provided and were students of the Faculty of Medicine, Udayana University who were undergoing the process of writing a 
thesis, in this case the class of 2017. The general condition was very good and could follow instructions. The research procedure began by distributing questionnaires as a process of collecting data on respondents regarding the symptoms of anxiety experienced by BAI (Beck Anxiety Inventory) (Tambunan, 2013). Calculations are made based on the points obtained from the respondents and then classified according to the level of anxiety according to the interpretation of the BAI (Beck Anxiety Inventory).

Table 1. Characteristics of Respondents Based on Major and Gender.

\begin{tabular}{llll}
\hline MAJOR & MALE & FEMALE & TOTAL \\
& N(\%) & N(\%) & \\
\hline MEDICAL & $18(36 \%)$ & $32(64 \%)$ & 50 \\
PUBLIC HEALTH & $4(14.3 \%)$ & $24(85.706)$ & 28 \\
NURSING & $7(25 \%)$ & $21(75 \% 6)$ & 28 \\
PHYSIOTHERAPY & $6(31.6 \%)$ & $13(68.4 \% 6)$ & 19 \\
DENSTISTRY & $9(33.3 \%)$ & $18(66.7 \% 6)$ & 27 \\
PSYCHOLOGY & $4(22.2 \%)$ & $14(77.846)$ & 18 \\
\hline TOTAL & $48(28.2 \%)$ & $122(71.896)$ & 170 \\
\hline
\end{tabular}

Source: Authors.

Characteristics of respondents based on gender and study program show that the majority are female with a different distribution between men and women in each of the existing major is shown in the Table 1.

Table 2. Overview of Anxiety Levels at the Faculty of Medicine, Udayana University Class of 2017 Related to Coping Mechanisms.

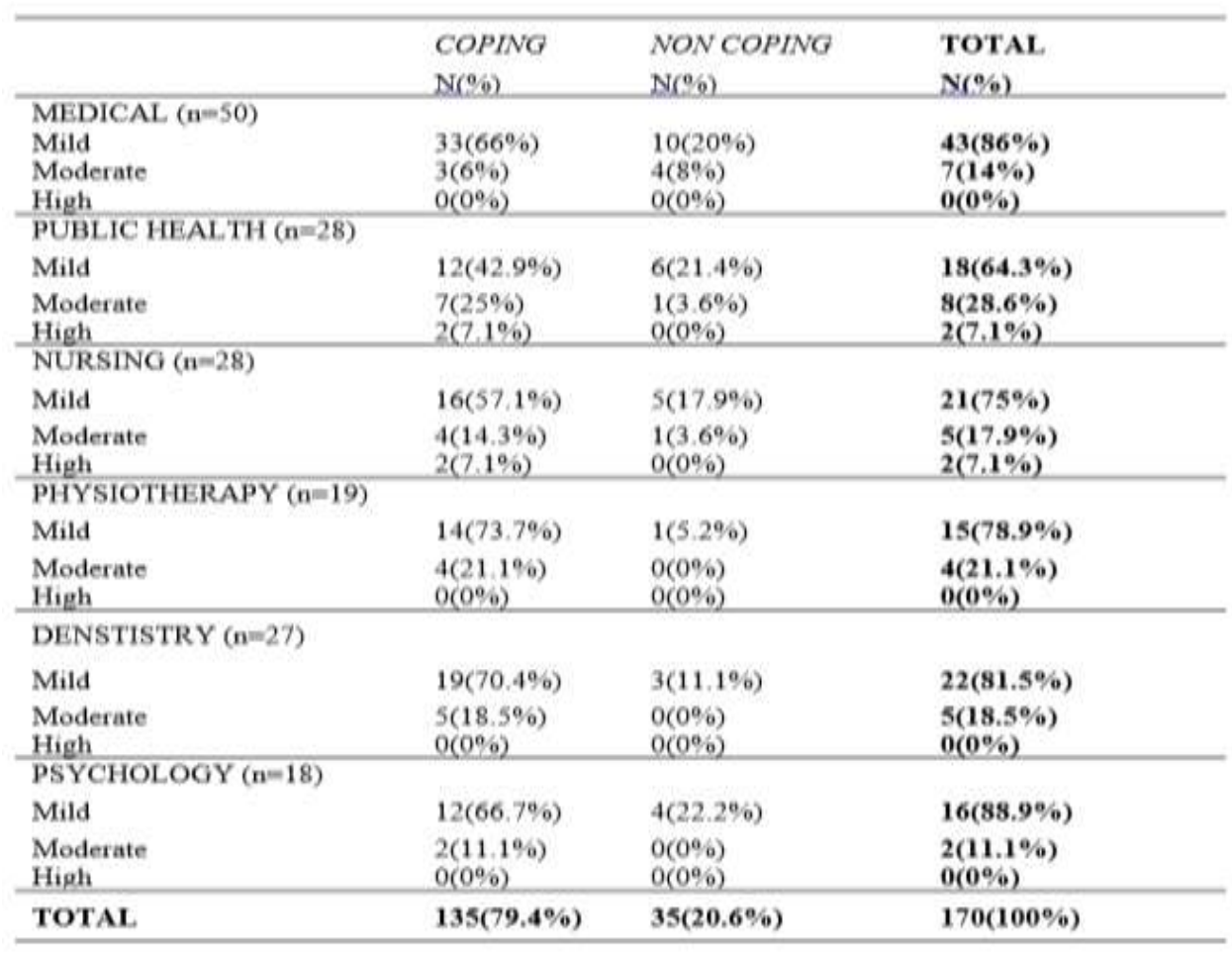

Source: Authors.

The number of respondents who have a hobby as a coping mechanism is more than those who do not have a hobby. 
For comparison of anxiety levels, similar results were found between those who have hobbies and those who do not have hobbies in each major, the level of mild anxiety is the most, followed by the level of moderate anxiety and the least is the level of high anxiety is shown in the Table 2 .

Table 3. Overview of Anxiety Levels at the Faculty of Medicine, Udayana University Class of 2017 Related to Student Involvement in Relationships.

\begin{tabular}{|c|c|c|c|}
\hline & $\begin{array}{l}\text { INVOLVED } \\
\text { N(\%) }\end{array}$ & $\begin{array}{l}\text { NOT INVOLVED } \\
\mathrm{N}(\%)\end{array}$ & $\begin{array}{l}\text { TOTAL } \\
\text { N(\%) }\end{array}$ \\
\hline \multicolumn{4}{|c|}{ MEDICAL $(\mathrm{n}=50)$} \\
\hline Mild & $21(42 \%)$ & $22(44 \%)$ & $43(86 \%)$ \\
\hline Moderate & $4(8 \%)$ & $3(6 \%)$ & $7(14 \%)$ \\
\hline High & $0(0 \%)$ & $0(0 \%)$ & $0(0 \%)$ \\
\hline \multicolumn{4}{|c|}{ PUBLIC HEALTH $(\mathrm{n}=28)$} \\
\hline Mild & $8(28.6 \%)$ & $10(35.7 \%)$ & $18(64.3 \%)$ \\
\hline Moderate & $6(21.5 \%)$ & $2(7.1 \%)$ & $8(28.6 \%)$ \\
\hline High & $2(7.1 \%)$ & $0(0 \%)$ & $2(7.1 \%)$ \\
\hline \multicolumn{4}{|c|}{ NURSING $(\mathrm{n}=28)$} \\
\hline Mild & $9(32.1 \%)$ & $12(42.9 \%)$ & $21(75 \%)$ \\
\hline Moderate & $1(3.6 \%)$ & $4(14.3 \%)$ & $5(17.9 \%)$ \\
\hline High & $0(0 \%)$ & $2(7.1)$ & $2(7.1 \%)$ \\
\hline \multicolumn{4}{|c|}{ PHYSIOTHERAPY $(\mathrm{n}=19)$} \\
\hline Mild & $7(36.8 \%)$ & $8(42.1 \%)$ & $15(78.9 \%)$ \\
\hline Moderate & $4(21.1 \%)$ & $0(0 \%)$ & $4(21.1 \%)$ \\
\hline High & $0(0 \%)$ & $0(0 \%)$ & $0(0 \%)$ \\
\hline \multicolumn{4}{|c|}{ DENTISTRY $(\mathrm{n}=27)$} \\
\hline Mild & $9(33.3 \%)$ & $13(48.2 \%)$ & $22(81.5 \%)$ \\
\hline Moderate & $0(0 \%)$ & $5(18.5 \%)$ & $5(18.5 \%)$ \\
\hline High & $0(0 \%)$ & $0(0 \%)$ & $0(0 \%)$ \\
\hline \multicolumn{4}{|c|}{ PSYCHOLOGY (n=18) } \\
\hline Mild & $5(27.8 \%)$ & $11(61.1 \%)$ & $16(38.9 \%)$ \\
\hline Moderate & $2(11.1 \%)$ & $0(0 \%)$ & $2(11.1 \%)$ \\
\hline High & $0(0 \%)$ & $0(0 \%)$ & $0(0 \%)$ \\
\hline TOTAL & $78(45.9 \%)$ & $92(54.1 \%)$ & $170(100 \%)$ \\
\hline
\end{tabular}

Source: Authors.

The number of respondents who who involved in relationship is less than those who do not have a relationship. in this case, the relationship in question is boyfriend. For comparison of anxiety levels, similar results were found between those who have a boyfriend and those who do not have a girlfriend in each study program, namely the highest level of mild anxiety, followed by moderate anxiety level and the least severe anxiety level is shown in the Table 3 .

\section{Discussion}

From the results of the research on anxiety in the implementation of the essay, the category with the most experienced was the mild anxiety category, which was 135 people (79.4\%), followed by the moderate category as many as 31 people (18.2\%) and the category with the smallest number was the high category with a total of 4 people. $(2.4 \%)$. In a study at the Faculty of Medicine, University of Lampung regarding anxiety, the results obtained were 222 students, 170 people (76.6\%) experienced moderate anxiety and 52 people (23.4\%) experienced high anxiety (Saba et al., 2018). In addition, it was also found that the diversity of results in 2020 on medical students at the "Veteran" Jakarta National Development University with the result that the majority of students experienced severe anxiety by $72 \%$ (Nurcita et al., 2020). The same thing was obtained from the results of Anissa's research in 2018 on nursing students at Padjadjaran University, namely the highest percentage was a mild anxiety level of $32.2 \%$ (Anissa et al., 2018). The diversity in the number in each category is caused by the anxiety response, coping mechanism and also the specific stressor of each individual is different. 
In terms of predisposing anxiety, especially in terms of psychology, the lack of emotional support in family or close people as well as the experience of individuals who have witnessed an anxiety response and experienced intense fear have a greater risk of experiencing anxiety or panic (Stuart, 2014). Emotional support is a support that is needed in reducing anxiety because it serves as a port of rest and recovery for emotional mastery in the form of expressions of empathy, care, and attention (Murharyati et al., 2021). In table 3, the number of students who have partners is less than those who have partners.

If viewed from the coping mechanism, is an individual's way of dealing with problems or demands that come from internal and external so it is important to be applied by students to overcome the academic stress experienced (Yunalia et al., 2021). In the table, it is found that the number of students who have hobbies is far more than those who do not have hobbies, of course, as an effort to avoid anxiety itself by utilizing problem solving skills, financial assets, social support or cultural beliefs that can be adopted.

Individual anxiety responses to a problem depend on the anxiety experienced, which means that increasing individual anxiety will increase the intensity of the response to anxiety (Annisa et al., 2016). Score will be calculated through the Beck Anxiety Inventory (BAI) assessment system which contains symptoms of anxiety both physiological and behavioral which often causes rapid and uncontrolled changes in physical and mental sensations and intensity of thought so that the level of anxiety obtained from each individual at the Faculty of Medicine, Udayana University class 2017 (Sitorus et al., 2016; Pratama, 2017).

Specific stressors are no less important in terms of individual anxiety levels. Which includes physical integrity and self-system threats. From the questionnaires distributed, it can be seen that students of the Faculty of Medicine, Udayana University class 2017 lead to special stressors that are self-system threats involving danger to one's identity or integrated social functions such as obstacles between students and supervisors, obstacles in the licensing process in research, there are remaining courses which must be completed at the same time as the process of compiling the final thesis, so as to provide a sense of anxiety for the individual concerned (Gunawati, 2005).

\section{Conclusion}

In this study, the anxiety level of the students of the Faculty of Medicine, Udayana University class 2017 was seen from the accumulated scores on the Beck Anxiety Inventory (BAI) questionnaire which was filled out by the students concerned. The level of anxiety in the 2017 Udayana University Faculty of Medicine students in the light category was 135 people (79.4\%) and the medium category was 31 people (18.2\%) and the heavy category was 4 people (2.4\%). For each study program, the level of anxiety experienced is relatively the same, namely the highest category in the mild category, then followed by the moderate category and the last with the smallest number, namely the severe category. Further research needs to be done on the special stressors experienced by students specifically related to their respective study programs.

\section{References}

Adiguna, J. Z. (2015). Hubungan antara tingkat stres psikis dengan derajat kebiasaan merokok pada dewasa muda perokok. SKRIPSI-2015.Anissa, L. M., Suryani, S., \& Mirwanti, R. (2018). Tingkat kecemasan mahasiswa keperawatan dalam menghadapi ujian berbasis computer based test. MEDISAINS, 16(2), 67-75.

Anissa, L. M., Suryani, S., \& Mirwanti, R. (2018). Tingkat kecemasan mahasiswa keperawatan dalam menghadapi ujian berbasis computer based test. MEDISAINS, 16(2), 67-75.

Annisa, D. F., \& Ifdil, I. (2016). Konsep kecemasan (anxiety) pada lanjut usia (lansia). Konselor, 5(2), 93-99.

Annisa, M. D. (2018). Hubungan Antara Konsep Diri Dengan Kecemasan Umum Pada Remaja Awal. Jurnal Psikologi, 10(2).

Chandratika, D., \& Purnawati, S. (2014). Gangguan Cemas pada Mahasiswa Semester I dan VII Program Studi Pendidikan Dokter Fakultas Kedokteran Universitas Udayana. E Jurnal Medika Udayana, 3(1), 403-414. 
Gunawati, R. (2005). Hubungan antara efektivitas komunikasi mahasiswa-dosen pembimbing utama skripsi dengan stres dalam menyusun skripsi pada mahasiswa Program Studi Psikologi Fakultas Kedokteran Universitas Diponegoro (Doctoral dissertation, Universitas Diponegoro).

Hariwijaya, M., \& Djaelani, M. (2008). Teknik menulis SKRIPSI dan THESIS: disertai contoh proposal skripsi. Hanggar Kreator.

Hastuti, R. Y., \& Arumsari, A. (2016). Pengaruh terapi hipnotis lima jari untuk menurunkan kecemasan pada mahasiswa yang sedang menyusun skripsi di STIKES Muhammadiyah Klaten. MOTORIK Jurnal Ilmu Kesehatan, 10(21).Jaadoon, N. A., Yaqoob, R., Raza, A. 2010 Anxiety and depression among medical student: a cross-sectional study, JMPA. The Journal of the Pakistan Medical Association, 60(8), p. 699-702.

Jaadoon, N. A., Yaqoob, R., Raza, A. 2010 Anxiety and depression among medical student: a cross-sectional study, JMPA. The Journal of the Pakistan Medical Association, 60(8), p. 699-702. Available at: http://europepmc.org/abstract/MED/20726214.

Lyndon, M. P., Strom, J. M., Alyami, H. M., Yu, T. C., Wilson, N. C., Singh, P. P., \& Hill, A. G. (2014). The relationship between academic assessment and psychological distress among medical students: a systematic review. Perspectives on medical education, 3(6), 405-418.

Marsella, F. P. (2018). Uji Validitas Konstruk Pada Instrumen Academic Anxiety Dengan Metode Confirmatory Factor Analysis (CFA). Volume IV Nomor 2 April 2015, 159.

Mastuti, N. P. (2010). Hubungan efikasi diri dengan problem focus coping dalam menyusun skripsi pada mahasiswa psikologi (Doctoral dissertation, Universitas Islam Negeri Sultan Syarif Kasim Riau).

Murharyati, A., Rusmilah, L., Solikhah, M., \& Pratiwi, E. (2021). Dukungan Emosional Keluarga Dengan Tingkat Kecemasan Pada Pasien Tuberkulosis (TB) PARU. Jurnal Ilmiah PANNMED (Pharmacist, Analyst, Nurse, Nutrition, Midwivery, Environment, Dentist), 16(1), 165-176.

NurCita, B., \& Susantiningsih, T. S. (2020). Dampak Pembelajaran Jarak Jauh Dan Physical Distancing Pada Tingkat Kecemasan Mahasiswa. Journal of Borneo Holistic Health, 3(1). Ottens, A. J. 1991. Coping with academic anxiety. New York: The Rosen Publishing Group.

Ottens, A. J. 1991. Coping with academic anxiety. The Rosen Publishing Group.

Pratama, H. A. (2017). Kecemasan Mahasiswa Menghadapi Osce Pada Program Profesi Ners Fakultas Ilmu Kesehatan Universitas Muhammadiyah Malang (Doctoral dissertation, University of Muhammadiyah Malang).

Saba, R. T., Lisiswanti, R., \& Cania, E. (2018). Hubungan Self-efficacy Terhadap Tingkat Kecemasan Mahasiswa Tingkat Pertama Fakultas Kedokteran Universitas Lampung. Jurnal Majority, 7(3), 12-16.

Sitorus, P. E., \& Fitrikasari, A. (2016). Gambaran Tingkat Kecemasan Dan Hubungannya Dengan Berbagai Faktor Pada Pasien Rawat Jalan Puskesmas (Studi Deskriptif Analitik Di Puskesmas Halmahera Semarang) (Doctoral dissertation, Diponegoro University).

Situmorang, D. D. B. (2016). Hubungan antara potensi kreativitas dan motivasi berprestasi mahasiswa Program Studi Bimbingan dan Konseling angkatan 2010 FKIP Unika Atma Jaya. Jurnal Bimbingan Konseling Indonesia, 1(1), 6-9.

Stuart, G. W. (2014). Principles and practice of psychiatric nursing-e-book. Elsevier Health Sciences.

Tambunan, S. I. (2013). Hubungan antara Obat Anti Epilepsi dengan Kognitif dan Behavior pada Pasien Epilepsi.

Thinagar, M. (2017). Wayan W. Tingkat kecemasan kedokteran udayana dan implikasinya pada hasil ujian. Intisari sains medis, 8(3), 181-183.

Yanti, S., Erlamsyah, E., Zikra, Z., \& Ardi, Z. (2013). Hubungan antara Kecemasan dalam Belajar dengan Motivasi Belajar Siswa. Konselor, 2(1).

Yunalia, E. M., Jayani, I., Suharto, I. P. S., \& Susilowati, S. (2021). Kecerdasan Emosional dan Mekanisme Koping Berhubungan dengan Tingkat Stres Akademik Mahasiswa. Jurnal Keperawatan Jiwa (JKJ): Persatuan Perawat Nasional Indonesia, 9(4), 869-878. 